\title{
Extent of Dissemination, Awareness, and Acceptability of the Revised LDCU Vision, Mission, and CAS Objectives among Students and Faculty
}

\author{
WINSTON B. GALLINERO \\ ORCID No. 0000-0002-2229-1262 \\ wgallinero@yahoo.com \\ VERGIE S. OTIG \\ ORCID No. 0000-0002-6062-5569 \\ mavbso6@yahoo.com \\ Liceo de Cagayan University \\ Cagayan de Oro City, Philippines
}

\begin{abstract}
This study determined the extent of dissemination of information, awareness, and degree of acceptability of the revised LDCU vision and mission and the CAS objectives among students and faculty. Descriptive research design was employed using a researcher-made survey questionnaire. Results show a moderate level of the extent of dissemination and awareness of the revised LDCU vision and mission and CAS objectives to both faculty and student-respondents. The finding suggests that information was disseminated properly and clearly through brochures, bulletin boards, leaflets, manuals, posters, and meetings. In terms of degree of acceptability, the results reveal that both faculty and studentrespondents accept the vision and mission and CAS objectives for "total human formation" and delivery of "quality education." Meanwhile, both faculty and student-respondents' profile shows no significant difference in their extent of dissemination and awareness and with their degree of acceptance of the revised LDCU vision and mission and CAS objectives. It can be implied that they come to accept the vision and mission regardless of their profile. Lastly, both faculty and students' extent of dissemination and degree of acceptability was found to have a significant difference. It can be deduced that if the information was disseminated clearly through different sources such as posters, bulletin boards, and the like the more they become aware by accepting the revised University's vision and mission and CAS objectives.
\end{abstract}


Keywords: Dissemination, awareness, acceptability, revised LDCU vision and mission, CAS objectives

\section{INTRODUCTION}

Every institution has a working philosophy. This philosophy is made up of three elements necessary for the institution's success. Its mission, vision, and core values that were structured right from the school's founding serves as its quality of education framework. It is the school's assurance of providing nothing less than an excellent quality of education for its students. As what Custodio (2003) points out that higher education are geared towards the provision of better education which is mandated by the Education Act of 1982.

However, a school is also a system. As a system it is also bound to change. This, as the school grows and develops, revisiting its aspirations and goals on a regular basis are imperative. Its vision and mission must be constantly expressed as it incorporates changes and additions reflecting the school's current circumstances; its new opportunities; and/or new goals. Similarly, Peterson (1995) as cited in the study of Alvior (2014) posits that schools need to build a clear vision which helps motivates students and staff to develop a sense of shared responsibility for student learning. It is in this context that Liceo de Cagayan University (LDCU) reviewed the University's vision, mission, and core values.

In LDCU's fifty-one years of service, the University has never slackened a step in pursuing its vision of bringing about positive change every day. Hence with its rich heritage and indefatigable present, LDCU once again redirects itself with a confident vision of a strong future. The vision, mission, and University goals were revised two years ago. This was initiated by the LDCU Administrators. By consulting the faculty members and the students, the school system's strengths and weaknesses were identified. That process presented and opportunity for the administrators to specify priority items for improvement. Using various forms of information materials, the revised University vision, mission, and goals were then disseminated to all LDCU community members. However, for the Licean to hear about these updates through orientation or read documents about the revisions are but superficial efforts in understanding the University's missions, vision, and goals. What the University wants to attain, most importantly, is for the Licean to accept, imbibe, and concretize the values in his or her daily activities. The relentless focus on successful classroom instruction is one proof that LDCU is moving closer, every day, in attaining this aim. 
Moreover, the University deemed that this objective can be fully realized in the coming years through the concentrated efforts of community members; most especially the administrators, faculty, and students. Strong support as well as wholehearted internalization is expected from them as they are an integral part of Liceo de Cagayan University's success story - a university committed to "Total Human Formation".

\section{OBJECTIVES OF THE STUDY}

This study looked into concerns regarding the extent of dissemination, awareness, and acceptability of LDCU's revised vision and mission as well as the College of Arts and Sciences' objectives.

Specifically, this study sought to: (1) determine the profile of the students in terms of course, year level, gender, and academic status; and the profile of the faculty in terms of gender, department, and employment status; (2) determine the extent of dissemination and awareness of the revised LDCU vision and mission and the CAS objectives; (3) determine the degree of acceptability of the LDCU revised vision and mission as well as the CAS objectives; (4) test the difference between the respondents' profile and the extent of dissemination, and awareness of the LDCU revised vision and mission and the CAS objectives; (5) test the difference between the extent of dissemination and awareness and degree of acceptability of LDCU revised vision and mission and the CAS objectives.

\section{FRAMEWORK}

The present study was anchored on the goal-setting theory by Edwin A. Locke in the 1960's. It was developed later by Locke and Latham (1990). This contends that goals can influence an individual's performance. Thus understanding how these goals would create an impact on individuals is important. Moreover, the basic theory behind goal-setting is that human behaviour is governed by goals and ambition. This theory is supported by Maslow and other motivation theorists. Those theorists emphasize the importance of conditions in which the individual can attain his or her own needs in fulfilling organizational goals (Lau and Shani, 1988) in the context of Liceo de Cagayan University, its vision and mission and CAS objectives has to be shared with all the members of the University such as administrators, faculty, staff, and students. According to Lau and Shani (1988), it is a step forward combining efforts with the organization's goals. Thus, goals need 
to be clear, attainable, specific, measurable, and realistic.

Furthermore, Lau and Shani (1988) suggest that goal-setting theory serves as an effective tool for measuring stakeholders to have awareness of what they must do to achieve the objective.

Locke and Latham $(1990,2002)$ posit that feelings of success in the workplace occur when stakeholders see that they will grow and surpass challenges especially the employees by pursuing and achieving goals that are important and meaningful to them. In the context of LDCU, its vision, mission, and objectives definitely provides excellent service to its constituents since it is for their own good. As what Alvior (2014) points out, Universities serve as "prime movers of change of society", need to exhibit exemplary practice. However, to make an academe relevant to the needs of its constituents, there is a need to evaluate its vision and mission statements. After a thorough evaluation, revision will surely follow and another evaluation if its disseminated well in the institution and make them aware which lead them to accept the revised vision, mission, and goals. Thus this research is made to determine whether LDCU constituents, specifically in the College of Arts and Science are aware of the revised LDCU vision and mission and CAS objectives and validate if the identified sources of dissemination are effective to make them aware and accept the revised LDCU vision and mission and CAS objectives as well.

Independent Variables

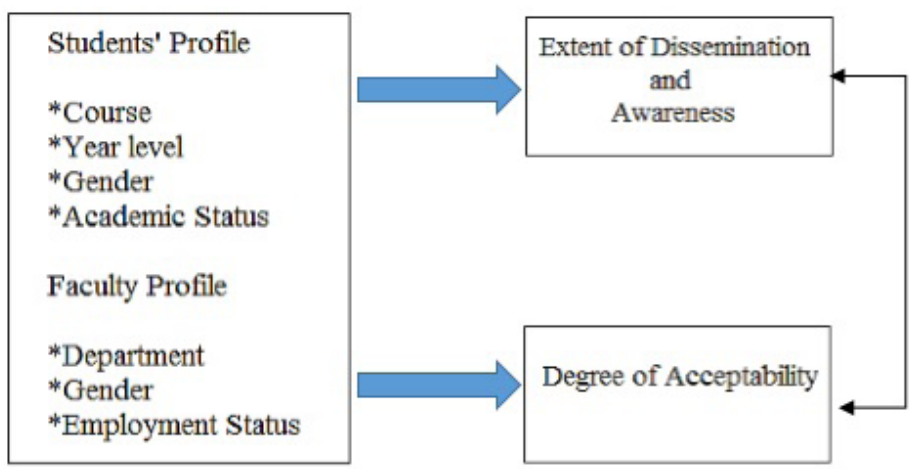

Figure 1. The Schema of the Study Showing the Interplay of the Independent and Dependent Variables 


\section{METHODOLOGY}

The study was conducted at the Main Campus of Liceo de Cagayan University specifically in the College of Arts and Sciences during the school year 2015-2016. The respondents of the study were the students and faculty of the College of Arts and Sciences, Liceo de Cagayan University.

Descriptive research design was employed in the study. Researcher-made questionnaire was used and pre-tested with a Cronbach's alpha of 0.872 which was a reliable instrument. The instrument has three parts. Part 1 consisted of the respondents profile such as students' course, year level, gender, and academic status while the faculty's profile includes gender, department, and employment status. Part 2 measured the respondents' extent of dissemination and awareness of the LDCU revised vision and mission as well as the CAS objectives. Part 3 measured the degree of acceptability of the LDCU revised vision and mission as well as the CAS objectives.

The survey questionnaires were administered by the researchers personally, while the students answered during the signing of clearance of CASSBO. A total of 102 respondents, 86 of which were students and 16 were faculty of CAS. However, other questionnaires were not returned by the students which made the turn out smaller but participated by all courses and departments in the College.

The data was then analyzed according to the objectives of the study and tabulated in a series of tables. Descriptive statistics such as frequency counts, percentages, means, ranks, and general weighted mean were used. Likewise, T-test will was employed to determine the significant differences of data gathered.

Furthermore, the survey questionnaire was answered in a Likert scale except for the profile. Part 2 comprises 7 items. The respondents indicated the extent to which a statement personally applied how the information was disseminated to them and to what extent and how much they are aware of the LDCU revised vision and mission and CAS objectives ranging from "Not at all disseminated/ aware" to "Extremely disseminated/aware". The choice responses were assigned a value of "Not at all disseminated/aware" scoring 1 and "Extremely disseminated/ aware" scoring 5. The responses were then tallied, analyzed, and interpreted, on the other hand, Part III comprises 10 items also in a Likert scale format ranging from "Strongly not acceptable" to "Strongly acceptable". Each response was given a value of 1 with "Strongly not acceptable" as the lowest and 5 "Strongly acceptable" as the highest. 


\section{Scoring Procedure}

Part 1. Extent of Dissemination and Awareness

\begin{tabular}{|c|c|c|}
\hline Scale & Range & Verbal Description \\
\hline 5 & $4.50-5.00$ & Extremely Disseminated/Aware \\
\hline 4 & $3.50-4.49$ & Moderately Disseminated/Aware \\
\hline 3 & $2.50-3.49$ & Somewhat Disseminated/Aware \\
\hline 2 & $1.50-2.49$ & Slightly Disseminated/Aware \\
\hline 1 & $1.00-1.49$ & Not at all Disseminated/Aware \\
\hline
\end{tabular}

Part 2. Degree of Acceptability

\begin{tabular}{|c|c|c|}
\hline Scale & Range & Verbal Description \\
\hline 5 & $4.50-5.00$ & Strongly Acceptable \\
\hline 4 & $3.50-4.49$ & Acceptable \\
\hline 3 & $2.50-3.49$ & Undecided \\
\hline 2 & $1.50-2.49$ & Not Acceptable \\
\hline 1 & $1.00-1.49$ & Strongly Not Acceptable \\
\hline
\end{tabular}

\section{RESULTS AND DISCUSSION}

This presents the analysis and interpretation of the data gathered. The presentation of the data follows the logical arrangement of the objectives of the study.

Table 1. Distribution of Respondents according to Profile

A. Students

\begin{tabular}{|l|c|c|}
\hline \multicolumn{1}{|c|}{ Course } & Frequency & Percent \\
\hline Psychology & 35 & 40.70 \\
\hline Biology & 5 & 5.81 \\
\hline Political Science & 7 & 8.14 \\
\hline Mass Com & 13 & 15.12 \\
\hline IS & 22 & 25.58 \\
\hline LPA & 2 & 2.33 \\
\hline BLIS & 1 & 1.16 \\
\hline BA English Lit. & 1 & 1.16 \\
\hline \multicolumn{1}{|c|}{ Total } & $\mathbf{8 6}$ & $\mathbf{1 0 0 . 0 0}$ \\
\hline \multicolumn{2}{|c|}{}
\end{tabular}




\begin{tabular}{|l|c|c|}
\hline Year Level & 19 & 22.09 \\
\hline First Year & 30 & 34.88 \\
\hline Second Year & 22 & 25.58 \\
\hline Third Year & 15 & 17.44 \\
\hline Fourth Year Total & $\mathbf{8 6}$ & $\mathbf{1 0 0 . 0 0}$ \\
\hline \multicolumn{2}{|c|}{} \\
\hline Gender & 19 & 22.09 \\
\hline Male & 67 & 77.91 \\
\hline Female Total & $\mathbf{8 6}$ & $\mathbf{1 0 0 . 0 0}$ \\
\hline \multicolumn{2}{|c|}{} \\
\hline Academic Status & 64 & 74.42 \\
\hline Regular & 22 & 25.58 \\
\hline Irregular & $\mathbf{8 6}$ & $\mathbf{1 0 0 . 0 0}$ \\
\hline
\end{tabular}

B. Faculty

\begin{tabular}{|c|c|c|}
\hline Gender & Frequency & Percent \\
\hline Male & 8 & 50.00 \\
\hline Female & 8 & 50.00 \\
\hline Total & 16 & 100.00 \\
\hline \multicolumn{3}{|l|}{ Department } \\
\hline BHSD & 5 & 31.25 \\
\hline Nat Sci & 5 & 31.25 \\
\hline Languages & 1 & 6.25 \\
\hline Math & 2 & 12.50 \\
\hline Soc Sci & 1 & 6.25 \\
\hline NSTP & 2 & 12.50 \\
\hline Total & 16 & 100.00 \\
\hline \multicolumn{3}{|l|}{ Employment Status } \\
\hline Regular & 9 & 56.25 \\
\hline Probationary & 5 & 31.25 \\
\hline Part-time & 2 & 12.50 \\
\hline Total & 16 & 100.00 \\
\hline
\end{tabular}

Table 1 shows the distribution of the respondents' profile to address the research first objective which is to determine the profile of the CAS students and faculty in terms of students: course, year and academic status; faculty: gender, department, and employment status.

The data revealed that 40.70 percent of the respondents come from Psychology which constitutes the highest percentage followed by IS with 25.58 percent. Mass Com represents 15.12 percent of the total number of respondents followed by 18.14 percent coming from Political Science while Biology constitutes 5.81 
percent. The courses which have the least number of respondents were LPA with 2.33 percent and 1.16 percent come from BLIS and BA Eng. Lit. respectively. This can be attributed to the fact that in terms of college enrolment, Psychology has the highest number of enrolees in the college during this year.

In terms of year level, the table shows that most respondents were second year with 34.88 percent followed by third year with 25.58 percent while the first year constitutes 22.09 percent. On the other hand, 4th year makes up the lowest in number with 17.44 percent.

With regard to gender, the data reveal that majority of the respondents are females making up 77.91 percent while males constitute about 22.09 percent of the total number of respondents. This can be attributed to the fact that in term of the college enrolment, females outnumbered males, thus the chance of getting more female respondents.

In terms of academic status, it shows that most of the respondents are regular students with 74.42 percent while 25.58 percent irregular students. This implies that most of the student-respondents started their freshman year in the College of Arts and Sciences.

The data in the table on the distribution of the faculty respondents in terms of gender shows that there is an equal distribution of both genders which constitutes 50.0 percent. It implies that men and women are now into the teaching profession. Traditional concept does not prevail hat teaching position is only for women due the nature of the work, which is tedious and meticulous, which generally women are more effective than men. However, in this study, female teachers outnumbered males but due to turned out rates of the survey questionnaires, the less chance of getting more female teachers.

With respect to department distribution, 31.25 percent belonged to BSHD and Nat Sci while 12.50 come from languages and Math and the least number of respondents belong to Soc Sci and NSTP respectively. This finding implies that the faculty members of the College of Arts and Sciences have varied experiences as determined by their status of employment in the University.

In terms of employment status, it shows that more than half of the respondents are regular faculty members with 56.25 percent while 31.25 percent are probationary and only 12.50 percent are part-time faculty. This implies that the faculty members are fully aware and knowledgeable of the revised vision and mission and CAS objectives since of them have regular status in the University. 
Table 2. Extent of Dissemination and Awareness of LDCU Revised Vision, Mission, and the Objectives of CAS as Assessed by the Students and Faculty

\begin{tabular}{|c|c|c|c|c|}
\hline \multirow[b]{2}{*}{ Indicators } & \multicolumn{2}{|r|}{ Students } & \multicolumn{2}{|r|}{ Faculty } \\
\hline & Mean & Verbal Description & Mean & Verbal Description \\
\hline $\begin{array}{l}\text { 1. Learned the vision and mission } \\
\text { of the University by heart. }\end{array}$ & 3.87 & $\begin{array}{c}\text { Moderately } \\
\text { Disseminated/Aware }\end{array}$ & 4.00 & $\begin{array}{c}\text { Moderately } \\
\text { Disseminated/Aware }\end{array}$ \\
\hline $\begin{array}{l}\text { 2. University's vision, mission, and } \\
\text { CAS objectives were clearly } \\
\text { disseminated. }\end{array}$ & 3.87 & $\begin{array}{c}\text { Moderately } \\
\text { Disseminated/Aware }\end{array}$ & 4.00 & $\begin{array}{c}\text { Moderately } \\
\text { Disseminated/Aware }\end{array}$ \\
\hline $\begin{array}{l}\text { 3. Aware of the objectives of each } \\
\text { of the programs of the CAS. }\end{array}$ & 3.83 & $\begin{array}{c}\text { Moderately } \\
\text { Disseminated/Aware }\end{array}$ & 4.38 & $\begin{array}{c}\text { Moderately } \\
\text { Disseminated/Aware }\end{array}$ \\
\hline $\begin{array}{l}\text { 4. The relevance of the vision, } \\
\text { mission, and the CAS objectives } \\
\text { were clearly explained. }\end{array}$ & 3.91 & $\begin{array}{c}\text { Moderately } \\
\text { Disseminated/Aware }\end{array}$ & 4.00 & $\begin{array}{c}\text { Moderately } \\
\text { Disseminated/Aware }\end{array}$ \\
\hline $\begin{array}{l}\text { 6.1 Aware of the University's } \\
\text { mission of delivering "Total } \\
\text { Human Formation." }\end{array}$ & 4.13 & $\begin{array}{c}\text { Moderately } \\
\text { Disseminated/Aware }\end{array}$ & 4.38 & $\begin{array}{c}\text { Moderately } \\
\text { Disseminated/Aware }\end{array}$ \\
\hline $\begin{array}{l}6.2 \text { Aware of the University's } \\
\text { mission of "Delivering Quality } \\
\text { Education." }\end{array}$ & 4.05 & $\begin{array}{c}\text { Moderately } \\
\text { Disseminated/Aware }\end{array}$ & 3.81 & $\begin{array}{c}\text { Moderately } \\
\text { Disseminated/Aware }\end{array}$ \\
\hline $\begin{array}{l}\text { 6.3 Aware of CAS objectives of } \\
\text { "Developing a Man for a Changing } \\
\text { Society". }\end{array}$ & 4.09 & $\begin{array}{c}\text { Moderately } \\
\text { Disseminated/Aware }\end{array}$ & 4.50 & $\begin{array}{c}\text { Extremely } \\
\text { Disseminated/Aware }\end{array}$ \\
\hline Grand Mean & 3.96 & $\begin{array}{c}\text { Moderately } \\
\text { Disseminated/Aware }\end{array}$ & 4.15 & $\begin{array}{c}\text { Moderately } \\
\text { Disseminated/Aware }\end{array}$ \\
\hline
\end{tabular}

Table 2 shows the mean rating of the respondents' extent of dissemination and awareness of the revised University's vision, mission, and CAS objectives. As shown in the table, all the items show a moderate dissemination and awareness with a Grand Mean (3.96). This implies that CAS students are aware of the vision, mission of the University and the CAS objectives. These are also disseminated by explaining to them during an orientation program at the beginning of the term.

On the other hand, the revised University's vision, mission, and CAS objectives are also moderately disseminated to the faculty members who make them aware of these with a Grand Mean (415). Hence, item 6.3 yields the highest mean (4.50). This finding reveals that faculty members are extremely aware of the CAS objectives of developing a "Man for a Changing Society" which are extremely disseminated especially during the orientation program at the beginning of the term. 
Table 3. Sources of Dissemination of LDCU Revised Vision, Mission, and CAS Objectives

\section{Students}

\begin{tabular}{|c|c|c|c|}
\hline \multirow{3}{*}{ Brochures } & Frequency & Percent & Rank \\
\cline { 2 - 4 } & 11 & 12.79 & $3^{\text {rd }}$ \\
\hline Leaflets & 3 & 3.49 & $5^{\text {th }}$ \\
\hline Manuals & 15 & 17.44 & $2^{\text {nd }}$ \\
\hline Bulletin boards & 51 & 9.30 & $4^{\text {th }}$ \\
\hline Posters & 4 & 4.65 & $7^{\text {th }}$ \\
\hline Catalogues & 0 & 0.00 & $7^{\text {th }}$ \\
\hline Meetings/Forum & 2 & 2.33 & $7^{\text {th }}$ \\
\hline $\begin{array}{c}\text { Social Orientation } \\
\text { Classes }\end{array}$ & 0 & 0.00 & \\
\hline $\begin{array}{c}\text { Integration with class } \\
\text { lessons }\end{array}$ & 0 & 0.00 & \\
\hline Total & $\mathbf{8 6}$ & $\mathbf{1 0 0}$ & \\
\hline
\end{tabular}

Faculty

\begin{tabular}{|c|c|c|c|}
\hline \multirow{3}{*}{ Bulletin boards } & Frequency & Percent & Rank \\
\cline { 2 - 4 } & 3 & 18.75 & $2^{\text {nd }}$ \\
\hline Posters & 13 & 81.25 & $1^{\text {st }}$ \\
\hline Total & $\mathbf{1 6}$ & $\mathbf{1 0 0}$ & \\
\hline
\end{tabular}

Table 3 shows the sources of dissemination of the University's vision, mission, and CAS objectives by ranking them. It reveals that bulletin boards rank first with 59.30 percent where the students got the information. Manuals are the second rank with 17.44 percent. There were no respondents answered catalogues, meeting, forums, SO classes, and integration with class lessons.

However, for faculty members the University's vision, mission, and CAS objectives were disseminated to them mostly through posters which ranked first with 81.25 percent and bulletin boards, 2nd rank with 18.75 percent. This implies that posting information especially the University's vision, mission, and CAS objectives on bulletin boards and posters are effective disseminating the information since faculty and students really read the updates written on the bulletin boards. 
Table 4. Respondents' Degree of Acceptability of LDCU Revised Vision, Mission, and CAS Objectives

\begin{tabular}{|c|c|c|c|c|}
\hline \multirow[b]{2}{*}{ Indicators } & \multicolumn{2}{|r|}{ Students } & \multicolumn{2}{|r|}{ Faculty } \\
\hline & Mean & Verbal Description & Mean & Verbal Description \\
\hline $\begin{array}{l}\text { Set A: On the University's vision and } \\
\text { mission } \\
\text { 1. I have faith in the University's vision } \\
\text { of total human formation. }\end{array}$ & 4.09 & Acceptable & 4.31 & Acceptable \\
\hline $\begin{array}{l}\text { 2. I am confident that the University is } \\
\text { capable of achieving its mission in } \\
\text { delivering quality instruction. }\end{array}$ & 4.05 & Acceptable & 4.44 & Acceptable \\
\hline $\begin{array}{l}\text { 3. I am with the University in its } \\
\text { commitment to the development of } \\
\text { values of discipline, loyalty, integrity, } \\
\text { excellence, and service. }\end{array}$ & 4.14 & Acceptable & 4.69 & Strongly Acceptable \\
\hline Grand Mean & 4.09 & Acceptable & 4.48 & Acceptable \\
\hline $\begin{array}{l}\text { Set B: On the Objectives of the College } \\
\text { of Arts and Sciences } \\
4 \text {. I am aware of and in full year } \\
\text { acceptance with CAS' commitment to } \\
\text { develop every student to become "a man } \\
\text { for a changing society." }\end{array}$ & 4.16 & Acceptable & 4.94 & Strongly Acceptable \\
\hline $\begin{array}{l}\text { 5. I have learned the values and skills of } \\
\text { self-awareness and human relations } \\
\text { integrated in all the curricular ad co- } \\
\text { curricular programs. }\end{array}$ & 4.10 & Acceptable & 4.81 & Strongly Acceptable \\
\hline $\begin{array}{l}\text { 6. I am willing to support and cooperate } \\
\text { the college pursuit of academic } \\
\text { competency ad excellence. }\end{array}$ & 4.26 & Acceptable & 4.38 & Acceptable \\
\hline $\begin{array}{l}\text { 7. I commend the objectives of } \\
\text { developing critical thinking as well as } \\
\text { the value of creativity and responsibility } \\
\text { as necessary in understanding the } \\
\text { changing society. }\end{array}$ & 4.29 & Acceptable & 4.56 & Strongly Acceptable \\
\hline $\begin{array}{l}\text { 8. I uphold all research undertakings } \\
\text { and special studies relevant to } \\
\text { instructional needs and development } \\
\text { needs of the society. }\end{array}$ & 4.13 & Acceptable & 4.50 & Strongly Acceptable \\
\hline $\begin{array}{l}\text { 9. I would like to impart my potentials, } \\
\text { abilities and resources, and engage } \\
\text { myself in services, projects, programs, } \\
\text { that contribute to the development of } \\
\text { our adopted communities and other } \\
\text { communities. }\end{array}$ & 4.23 & Acceptable & 4.44 & Acceptable \\
\hline $\begin{array}{l}\text { 10. I favour the building of close } \\
\text { interaction and partnerships with } \\
\text { industries to ensure relevance of } \\
\text { programs, research, training, job } \\
\text { placements, and other support } \\
\text { programs. }\end{array}$ & 4.23 & Acceptable & 4.31 & Acceptable \\
\hline Grand Mean & 4.20 & Acceptable & 4.56 & Strongly Acceptable \\
\hline
\end{tabular}

Table 4 shows the mean rating of the respondents' degree of acceptability of the University's vision, mission, and CAS objectives. In terms of the University's vision and mission. All the items reveal acceptable with a Grand Mean (4.09). It means that most of the students accept the vision and mission of LDCU. This 
implicates that they have faith in the vision of total human formation, confident that the University is capable of delivering quality instruction and its commitment to the development of core values such as discipline, loyalty, integrity, excellence, and service. With regard to the objectives of CAS, most of the students also fully accept the CAS commitment to develop every student to become "a man for a changing society", learned the values and skills of self-awareness, support academic competency, develop critical thinking, uphold research undertakings, impart their potentials and build close interaction with industries and the like.

For the faculty, the data show that most of them accept the University's vision and mission with a Gran Mean (4.48). Hence, item 3 yields the highest mean which states that "I am with the University in its commitment to the development of values of discipline, loyalty, integrity, excellence, and service. It reveals that the faculty strongly accept this. It can be attributed to the fact that teachers have a close interaction with students to develop such core values.

In terms of the objectives of CAS, the data reveal that most of the faculty strongly accept the CAS objectives with a Grand Mean (4.56) which describes as strongly acceptable. This finding shows that faculty in the College are actively involved in molding students to prepare them for a changing society.

Table 5. Test of Difference in the Extent of Dissemination and Awareness and Degree of Acceptability of LDCU Revised Vision, Mission, and CAS Objectives

\begin{tabular}{|c|c|c|c|c|}
\hline \multirow{4}{*}{ Students } & Indicators & Mean & Qualitative Description & T-test Result \\
\hline & $\begin{array}{l}\text { *Extent of } \\
\text { Dissemination } \\
\text { and } \\
\text { Awareness }\end{array}$ & 3.96 & $\begin{array}{c}\text { Moderately } \\
\text { disseminated/aware }\end{array}$ & \multirow{3}{*}{$\begin{array}{l}\text { T calculated value }=- \\
2.02 \\
\text { Degrees of Freedom }= \\
157 \\
\text { P-value }=0.045 \\
\text { Conclusion: } \mathrm{T} \\
\text { calculated value }>\mathrm{T} \\
\text { critical value } \\
\text { Interpretation }= \\
\text { Significant } \\
\end{array}$} \\
\hline & $\begin{array}{l}\text { * Degree of } \\
\text { Acceptability }\end{array}$ & 4.17 & Acceptable & \\
\hline & Difference & -0.21 & & \\
\hline \multirow{4}{*}{ Faculty } & Indicators & Mean & Qualitative Description & T-test Result \\
\hline & $\begin{array}{l}\text { *Extent of } \\
\text { Dissemination } \\
\text { and } \\
\text { Awareness }\end{array}$ & 4.15 & $\begin{array}{c}\text { Moderately } \\
\text { disseminated/aware }\end{array}$ & \multirow{3}{*}{$\begin{array}{l}\text { T calculated value }=- \\
3.99 \\
\text { Degrees of Freedom }= \\
25 \\
\text { P-value }=0.001 \\
\text { Conclusion: } \mathrm{T} \\
\text { calculated value }>\mathrm{T} \\
\text { critical value } \\
\text { Interpretation }= \\
\text { Significant }\end{array}$} \\
\hline & $\begin{array}{l}\text { * Degree of } \\
\text { Acceptability }\end{array}$ & 4.54 & Strongly Acceptable & \\
\hline & Difference & -0.39 & & \\
\hline
\end{tabular}


Table 5 reveals the tests of differences between the respondents' extent of dissemination and awareness and degree of acceptability of the revised University's vision. Mission and the CAS objectives. This is to address the fourth objective that sought to determine whether there is a significant difference between dissemination and awareness and acceptability of the LDCU's vision, mission, and CAS objectives. This is to address the fourth objective that sought to determine whether there is a significant difference between dissemination and awareness and acceptability of the LDCU vision and mission and CAS objectives.

As shown in the table, $\mathrm{t}$-value is -2.02 with a $\mathrm{p}$-value of 0.045 . It reveals that T-value is greater than t-critical which rejects the null hypothesis ( $\mathrm{HO})$ and is interpreted as significant. It shows that students' awareness is significantly related to acceptability of LDCU vision, mission, and CAS objectives. This implies that if students are aware of the information and it is disseminated clearly then they would also accept it.

For faculty, it reveals in the data that the t-value is -3.99 with a p-value of 0.001 is interpreted as significant. It implies that faculty's awareness has a significant difference with their acceptability of the LDCU vision, mission, and the CAS objectives. This implies that the vision, mission and CAS objectives are well disseminated which makes them fully aware of the revised LDCU vision mission, and CAS objectives and also come to strongly accept those. The present study validates the goal-setting theory of Locke and Latham (1990) contention that goals can influence performance. Since the LDCU vision and mission and CAS objectives are clear, measurable, specific, attainable and realistic, then the faculty and students of LDCU are motivated to internalize and accept the said goals and objectives.

Table 6. Test of Difference in the Extent of Dissemination and Awareness and Degree of Acceptabilty of LDCU Revised Vision, Mision, and CAS Objectives when the Students were Grouped according to Selected Variables

\begin{tabular}{|c|c|c|c|c|c|}
\hline Variables & Mean & Verbal Description & Statistics & P-value & Decision \\
\hline Course & & & & & \\
\hline Psychology & 4.11 & Moderately Disseminated/Aware & \multirow{8}{*}{$\mathrm{F}=1.43$} & \multirow{8}{*}{0.204} & \multirow{8}{*}{ Accept HO } \\
\hline Biology & 4.60 & Extremely Disseminated/Aware & & & \\
\hline Pol Sci & 3.78 & Moderately Disseminated/Aware & & & \\
\hline Mass Com & 3.92 & Moderately Disseminated/Aware & & & \\
\hline IS & 3.69 & Moderately Disseminated/Aware & & & \\
\hline LPA & 3.86 & Moderately Disseminated/Aware & & & \\
\hline BLIS & 3.29 & Somewhat Disseminated/Aware & & & \\
\hline $\begin{array}{l}\text { BA English } \\
\text { Lit. }\end{array}$ & 4.75 & Extremely Disseminated/Aware & & & \\
\hline
\end{tabular}




\begin{tabular}{|c|c|c|c|c|c|}
\hline Year level & & & & & \\
\hline $1^{\text {st }}$ year & 3.71 & Moderately Disseminated/Aware & \multirow{4}{*}{$\mathrm{F}=28.3$} & \multirow{4}{*}{0.043} & \multirow{4}{*}{ Reject HO } \\
\hline 2nd year & 4.26 & Moderately Disseminated/Aware & & & \\
\hline $3^{\text {rd }}$ year & 3.79 & Moderately Disseminated/Aware & & & \\
\hline $4^{\text {th }}$ year & 3.94 & Moderately Disseminated/Aware & & & \\
\hline \multicolumn{6}{|l|}{ Gender } \\
\hline Male & 3.89 & Moderately Disseminated/Aware & \multirow[b]{2}{*}{$\mathrm{t}=0.40$} & \multirow[b]{2}{*}{0.689} & \multirow[b]{2}{*}{ Accept HO } \\
\hline Female & 3.99 & Moderately Disseminated/Aware & & & \\
\hline \multicolumn{6}{|c|}{ Academic Status } \\
\hline Regular & 3.98 & Moderately Disseminated/Aware & \multirow[b]{2}{*}{$\mathrm{t}=0.22$} & \multirow[b]{2}{*}{0.827} & \multirow[b]{2}{*}{ Accept HO } \\
\hline Irregular & 3.93 & Moderately Disseminated/Aware & & & \\
\hline
\end{tabular}

Table 6 presents the tests of differences on the extent of dissemination when the students were grouped according to selected variables. When grouped according to the course of the study, the p-value 0.204 was greater than significance level of 0.05 . Hence, the null hypothesis concept cannot be rejected. This finding indicates that most of the CAS students are moderately aware of the revised LDCU's vision and mission and CAS objectives regardless of course. However, Biology and BA English Lit. revealed an extreme dissemination and awareness of the revised vision and mission statements as well as CAS objectives. BLIS disclosed the lowest mean which interpreted as somewhat disseminated/aware. This can be attributed to the fact that there was only one respondent from this course.

In terms of year level, the p-value of 0.043 was lesser than the significance level of 0.05 which led to reject the null hypothesis. This result implies that year level matters on how information was disseminated to them which makes them aware of the revised LDCU vision and mission and CAS objectives. It can be attributed to their length of stay in the University. The longer they stay, the more they become aware of the updates of the revised LDCU vision and mission and CAS objectives.

The p-value for gender was 0.089 which exceeds the alpha level of .05 . Thus, the null hypothesis was not rejected. This indicates that the extent of dissemination and awareness of the revised LDCU vision, mission, and CAS objectives are also moderately disseminated/aware regardless of students' gender.

On the aspect of academic status, the resulting p-value of 0.827 was greater than the significance level of .05 , which led to the acceptance of the null hypothesis. Results implied that the extent of dissemination and awareness is similarly moderate to both regular and irregular students.

The overall finding indicated that there were no significant differences in the extent of dissemination and awareness of the revised LDCU vision and mission and CAS objectives when grouped according to course of study, year level, gender, and academic status. 
Table 7. Tests of Differences of the Degree of Acceptability of LDCU Revised Vision and Mission and CAS Objectives when the Students were Grouped according to Selected Variables

\begin{tabular}{|c|c|c|c|c|c|}
\hline Variables & Mean & Verbal Description & Statistics & P-value & Decision \\
\hline Course & & & & & \\
\hline Psychology & 4.26 & Acceptable & \multirow{8}{*}{$\mathrm{F}=0.70$} & \multirow{8}{*}{0.671} & \multirow{8}{*}{ Accept HO } \\
\hline Biology & 4.48 & Acceptable & & & \\
\hline Pol Sci & 4.09 & Acceptable & & & \\
\hline Mass Com & 4.16 & Acceptable & & & \\
\hline IS & 3.99 & Acceptable & & & \\
\hline LPA & 4.30 & Acceptable & & & \\
\hline BLIS & 4.00 & Acceptable & & & \\
\hline BA English Lit. & 4.10 & Acceptable & & & \\
\hline \multicolumn{6}{|l|}{ Year level } \\
\hline $1^{\text {st }}$ year & 4.11 & Acceptable & \multirow{4}{*}{$\mathrm{F}=0.48$} & \multirow{4}{*}{0.69} & \multirow{4}{*}{ Accept HO } \\
\hline 2nd year & 4.26 & Acceptable & & & \\
\hline $3^{\text {rnd }}$ year & 4.08 & Acceptable & & & \\
\hline $4^{\text {th }}$ year & 4.19 & Acceptable & & & \\
\hline \multicolumn{6}{|l|}{ Gender } \\
\hline Male & 3.89 & Acceptable & \multirow[b]{2}{*}{$\mathrm{t}=0.35$} & \multirow[b]{2}{*}{0.727} & \multirow[b]{2}{*}{ Accept HO } \\
\hline Female & 3.99 & Acceptable & & & \\
\hline \multicolumn{6}{|l|}{ Academic Status } \\
\hline Regular & 3.98 & Acceptable & \multirow[b]{2}{*}{$t=0.00$} & \multirow[b]{2}{*}{0.997} & \multirow[b]{2}{*}{ Accept HO } \\
\hline Irregular & 3.93 & Acceptable & & & \\
\hline
\end{tabular}

Table 7 shows the tests of differences in the degree of acceptability of revision of LDCU vision and mission and CAS objectives when the students are grouped according to selected variables.

In terms of course, the p-value of 0.671 exceeds the level of significance of 0.05 . Hence, null hypothesis was not rejected. Results indicate that the revised LDCU vision and mission and the CAS objectives exhibited a degree of acceptability which is favourable to all courses.

Furthermore, the null hypothesis for year level was not rejected in the sense that the p-value of 0.69 was higher than the level of significance of 0.05 . This implies that the degree of acceptability is favourable to all year levels.

Meanwhile, the null hypothesis was not rejected when the students were grouped according to their gender. This was so because the p-value of 0.727 was greater than the significance level of 0.05 . Thus, there was no observed difference in the degree of acceptability according to gender, either males or females. They disclosed that they were acceptable of the revised LDCU vision, mission and the CAS objectives regardless of their gender.

In terms of academic status, both regular and irregular students expressed acceptability of the revised LDCU vision and mission and CAS objectives. This was supported by the p-value of 0.997 which was greater than the significance 
level of 0.05 . Hence, the null hypothesis was not rejected in this variable.

The overall finding favourably indicated that the revised LDCU vision and mission and CAS objectives gained a wide acceptance by the students regardless of course, year level, gender, and academic status.

Table 8. Tests of Differences on the Extent of Dissemination and Awareness of LDCU Revised Vision and Mission and CAS Objectives when the Faculty were Grouped according to Selected Variables

\begin{tabular}{|c|c|c|c|c|c|}
\hline Variables & Mean & Verbal Description & Statistics & P-value & Decision \\
\hline \multicolumn{6}{|l|}{ Department } \\
\hline BSHD & 4.00 & Moderately Disseminated/Aware & \multirow{6}{*}{$\mathrm{F}=0.81$} & \multirow{6}{*}{0.569} & \multirow{6}{*}{ Accept HO } \\
\hline Nat Sci & 4.11 & Moderately Disseminated/Aware & & & \\
\hline Languages & 4.43 & Moderately Disseminated/Aware & & & \\
\hline Math & 4.43 & Moderately Disseminated/Aware & & & \\
\hline Soc Sci & 4.00 & Moderately Disseminated/Aware & & & \\
\hline NSTP & 4.14 & Moderately Disseminated/Aware & & & \\
\hline \multicolumn{6}{|l|}{ Gender } \\
\hline Male & 4.54 & Extremely Disseminated/Aware & \multirow[b]{2}{*}{$\mathrm{t}=0.00$} & \multirow[b]{2}{*}{1.000} & \multirow[b]{2}{*}{ Accept HO } \\
\hline Female & 4.54 & Extremely Disseminated/Aware & & & \\
\hline \multicolumn{6}{|c|}{ Employment Status } \\
\hline Regular & 4.54 & Extremely Disseminated/Aware & \multirow{3}{*}{$\mathrm{F}=0.18$} & \multirow{3}{*}{0.837} & \multirow{3}{*}{ Accept HO } \\
\hline Probationary & 4.56 & Extremely Disseminated/Aware & & & \\
\hline Part-time & 4.45 & Moderately Disseminated/Aware & & & \\
\hline
\end{tabular}

Table 8 reveals the tests of differences on the extent of dissemination and awareness of the revised LDCU vision and mission and the CAS objectives when the faculty were grouped according to department, gender, and employment status.

In terms of academic department, the p-value of 0.569 was greater than the significance level of .05 . As such, the null hypothesis was not rejected for the variable. Results disclosed that the faculty from the different departments exhibited a moderate dissemination/awareness of the revised LDCU vision and mission and CAS objectives.

Furthermore, the null hypothesis for gender was not rejected since the p-value of 1.000 was greater than the alpha level of 0.05 which was interpreted as not significant. It can be discerned that the revised LDCU vision and mission and CAS objectives was extremely disseminated/aware to both male and female faculty members through posters and bulletin boards.

With regard to employment status, both regular and probationary faculty expressed an extreme dissemination of the revised LDCU vision and mission and CAS objectives which make them extremely aware as well. This was supported by 
the insignificant p-value of 0.837 , which was greater than the alpha level of .05 . Hence, the null hypothesis was not rejected in this variable.

The overall finding favourably indicated that the revised LDCU vision and mission and the CAS objectives gained a wide dissemination and awareness by the faculty regardless of department, gender, and employment status.

Table 9. Tests of Differences in the Degree of Acceptability of LDCU Revised Vision and Mission and CAS Objectives when the Faculty were Grouped according to Department, Gender, and Employment Status

\begin{tabular}{|c|c|c|c|c|c|}
\hline Variables & Mean & Verbal Description & Statistics & P-value & Decision \\
\hline Department & & & & & \\
\hline BSHD & 4.54 & Strongly Acceptable & \multirow{6}{*}{$\mathrm{F}=0.77$} & \multirow{6}{*}{0.595} & \multirow{6}{*}{ Accept HO } \\
\hline Nat Sci & 4.42 & Acceptable & & & \\
\hline Languages & 4.75 & Strongly Acceptable & & & \\
\hline Math & 4.65 & Strongly Acceptable & & & \\
\hline Soc Sci & 4.50 & Strongly Acceptable & & & \\
\hline NSTP & 4.50 & Strongly Acceptable & & & \\
\hline \multicolumn{6}{|l|}{ Gender } \\
\hline Male & 4.54 & Strongly Acceptable & \multirow[b]{2}{*}{$t=0.00$} & \multirow[b]{2}{*}{1.000} & \multirow[b]{2}{*}{ Accept $\mathrm{HO}$} \\
\hline Female & 4.54 & Strongly Acceptable & & & \\
\hline \multicolumn{6}{|c|}{ Employment Status } \\
\hline Regular & 4.54 & Strongly Acceptable & \multirow{3}{*}{$\mathrm{F}=0.18$} & \multirow{3}{*}{0.837} & \multirow{3}{*}{ Accept HO } \\
\hline Probationary & 4.56 & Strongly Acceptable & & & \\
\hline Part-time & 4.45 & Acceptable & & & \\
\hline
\end{tabular}

Table 9 presents the tests of differences in the degree of acceptability of the revised LDCU vision and mission and the CAS objectives when the faculty were grouped according to department, gender, and employment status. T-test was employed for gender and one-way anova for department and employment status.

In terms of the different academic departments, $\mathrm{p}$-value of 0.595 was greater than the significance level of 0.05 which led to the acceptance of the null hypothesis. Results indicated that the revised LDCU vision and mission and the CAS objectives gained a strong acceptability to the faculty regardless of which department they belong except for the Natural Sciences which also exhibit a favourable acceptability of the revised LDCU vision and mission and the CAS objectives.

With regard to gender, the null hypothesis was not rejected with a p-value of 1.000 which was greater than the significance level of 0.05 . Results implied that the faculty's degree of acceptability of the revised LDCU vision and mission and the CAS objectives was strong or highly acceptable to both male and female faculty members. 
Furthermore, the null hypothesis for employment status was also not rejected since the p-value was 0.837 which was greater than the significance level of 0.05 . It can be gleaned from the result that regular and probationary faculty strongly accept the revised LDCU vision and mission and the CAS objectives except for the part-timers.

\section{CONCLUSIONS}

From the findings of the study, it can be deduced that the revised LDCU mission and vision and CAS objectives were moderately disseminated to both faculty and students. Both faculty and student- respondents disclosed that the revisions were extensively disseminated during orientation programs at the beginning of the term and thus explained clearly to them. The faculty members concurred that these were disseminated through posters and bulletin boards while students' sources of information, include brochures, manuals, leaflets, posters, and meetings. On the degree of acceptability, the faculty exhibited very high acceptability of the LDCU's revised vision and mission, as well as the CAS objectives while students revealed acceptability of the same. However, both faculty and student-respondents' profile reveals no significant difference on their awareness and acceptability of the revised LDCU vision, mission and CAS objectives.

Furthermore, when faculty and student-respondents' extent of dissemination and awareness was tested with degree of acceptability, it was found to have a significant difference. This finding also validates the study of Compelio et al., (2015) that students have moderate awareness and acceptance of the LDCU vision and mission and the CAS objectives. The higher the extent of dissemination, the more accepting they are.

\section{RECOMMENDATIONS}

Based on the significant findings and the conclusions reached, this study recommends the following:

1. Under the supervision of the Department Chairpersons, the CAS Program Coordinators should conduct a departmental forum. This is to enhance the students' understanding of the CAS objective "Man for a Changing Society". Moreover, integrating the objectives in related major subjects could further enhance comprehension and assist in a more effective acceptance of this specific 
objective.

2. During the general orientation program and the departmental orientation at the start of each term, the major concept of "quality education" - which is central focus of the revised LDCU vision and mission - should be explained and discussed thoroughly. One important focus of discussion should be about explaining the specific parameters in the pursuit of "quality education".

3. The Department Chairpersons, under the supervision of the College Dean, should develop relevant measures and strategies in every curricular and cocurricular programs that could improve integration of self-awareness and human relations skills. The Department Chairperson could get assistance from the SBO officers when conducting enhancing sessions for the mentioned areas of concern.

4. Other colleges of the University may conduct a similar study. This could serve as an institutional research output on the extent of the dissemination and acceptability of the revised vision, mission, and core values.

5. Test of hypothesis for the relationship between the acceptability of the College's program objectives (as an independent variable) and the acceptability of the University's vision, mission, and core values (as dependent variable) is highly recommended.

\section{LITERATURE CITED}

Alvior, Mary G. (2014). A study on the vision and mission of the Palawan State University and the goal and program objectives of its graduate school. Retrieved from simplyeducate.me/2014/05/28/a-study-on-the-vision -and-mission-of-the-palawan-state-university-and-the-goal-andprogram-objectives-of-its-graduate-school.

Castillo, R. (2014). Awareness, acceptance and perception of Batangas State University stakeholders towards its VMGO. International journal of sciences: Basic and applied Research. Vol. 14, No. 1. Retrieved from gssr.org/index.php?journal=JournalofBASICANDApplied\&page.

Compelio, K.J., Caranto, L., \& David, J.J. (2015). Awareness, understanding, and acceptance of student nurses of the vision, mission, goals, and objectives of Benguet State University. International Journal of Nursing Science 2015. Retrieved from www.sapub.org/global/showpaperpdf. aspx?doi $=10.5923 /$ j.nursing. 
Custodio, L. (2003). Survey on awareness/acceptance of the Catanduanes colleges philosophy, vision and mission and the objectives of the graduate school, SY 2002-2003. Retrieved from ccs.adnu.edu.ph /era/rtf/1069.rtf.

Eddie, M.A, Pena, G., Agunos, E., Pacador, C., \& Poja, J. (n.d.). Client's Awareness and Acceptability of a College's Vision, Mission, and Goals. Retrieved from https.www.researchgate.net/...25957167/-Client's Awareness and Acceptability of a College's Vision, Mission and Goals.

Lau, J.B. \& Shani, A.B. (1988). Leadership and organizational styles. In behavior in organizations: An experimental approach, edited by James B. Lau and A.B. Shani, 41-76. Homeraod, IL: Irwin. Google Scholar

Locke, E.A. \& Latham, G.P. (1990). A Theory of Goal-Setting and Task Performance. Retrieved from https.//home.ubalt.edu. 